\title{
PERBAIKAN INSTRUKSIONAL DALAM IMPLEMENTASI ASSESSMENT-BASED LEARNING DI KELAS MATEMATIKA
}

\author{
Yoppy Wahyu Purnomo \\ FKIP Universitas Muhammadiyah Prof. DR. HAMKA \\ email: yoppy.w.purnomo@uhamka.ac.id
}

\begin{abstract}
Abstrak: Tujuan penelitian untuk mengidentifikasi perbaikan instruksional calon guru lewat implementasi assessment-based learning pada pembelajaran matematika di sekolah dasar. Penelitian dilakukan dengan participatory action research yang dan prosedur lesson study. Subjek penelitian adalah lima calon guru sekolah dasar yang sedang praktik pengalaman lapangan di sekolah dasar di Jakarta Timur. Data dikumpulkan lewat pengamatan, wawancara, dokumentasi, dan jurnal, sedang analisis data dilaksanakan secara deskriptif kualitatif. Hasil penelitian menemukan bahwa secara kolaboratif, calon guru berupaya untuk memodifikasi praktik dan meningkatkan perhatian terhadap pertanyaan terbuka dan penilaian sejawat. Perbaikan instruksional terjadi bersamaan dengan perbaikan implementasi assessment-based learning. Calon guru lebih dapat memaksimalkan umpan balik sebagai cara untuk mengakses perkembangan belajar siswa secara lebih komprehensif dan melakukan perbaikan instruksional. Kegiatan lesson study memberikan umpan balik secara langsung kepada calon guru untuk melakukan refleksi diri dan mendapat masukan dari teman sejawat.
\end{abstract}

Kata kunci: assessment-based learning, lesson study, pembelajaran matematika, calon guru sekolah dasar, praktik instruksional

\section{THE INSTRUCTIONAL IMPROVEMENT IN THE IMPLEMENTATION OF ASSESSMENT-BASED LEARNING IN MATHEMATICS CLASS}

\begin{abstract}
The purpose of this study is to identify the instructional improvement of pre-service teachers in implementing assessment-based learning $(A B L)$ in the mathematics learning at elementary school. This study employed participatory action research by adopting lesson study procedures. The subject was five pre-service elementary school teachers engaged early field experiences in one of the elementary schools in East Jakarta in the 2015/2016 academic year. The data were collected from the written response of the two independent observers, video recordings, interviews, student worksheets, and journal notes both student and teacher. The coding was done to identify the indicators of potential changes in the instructional practices. The study indicates that (1) pre-service teachers collaboratively sought to modify their practices and improve their attention to open-ended questions and peer-assessment as the elements of $A B L$; (2) instructional improvements occurred when they attempted to take corrective action in the $A B L$. This suggests that the pre-service teachers can maximize feedback as the way to make instructional improvements. The study also identifies some of the advantages generated from the implementation of lesson study implicitly. The lesson study activities provided the pre-service teachers feedback directly to have self-reflection and got feedback from peers.
\end{abstract}

Keywords: assessment-based learning, lesson study, mathematics learning, pre-service elementary school teachers, instructional practices

\section{PENDAHULUAN}

Secara garis besar, penelitian pendidikan matematika pada umumnya mengarah pada bagaimana cara terbaik untuk meningkatkan hasil belajar siswa dan mengantarkan mereka untuk belajar dengan pemahaman. Namun demikian, saran hasil penelitian belum terlihat sepenuhnya pada proses belajar dan mengajar di kelas. Kecenderungan praktik mengajar yang saat ini masih dipertahankan adalah praktik yang lebih berorientasi pada performa dan hasil. Hal ini dapat dibuktikan dengan melihat persiapan sekolahsekolah dalam menghadapi ujian nasional, ujian semester, dan ujian-ujian tertentu. Salah satu ciri 
yang menonjol adalah peningkatan intensitas mengerjakan latihan-latihan soal yang orientasinya untuk lulus dalam ujian-ujian tersebut.

Praktik mengajar yang berorientasi pada performa dan hasil menuntun pada praktik penilaian yang hanya digunakan untuk mengidentifikasi pengetahuan atau keterampilan yang disimpan setelah satuan pembelajaran selesai (Delandshere, 2002; Earl, 2003; James et al., 2006). Praktik penilaian yang berorientasi pada performa lebih fokus menekankan skor (nilai) daripada belajar, memisahkan penilaian dari proses pembelajaran, mendorong pembelajaran hafalan dan superfisial, mengabaikan pembelajaran bermakna, tidak memperhatikan kesulitan belajar yang mungkin dialami siswa menjadi pendorong pada kecemasan berlebih, berpengaruh pada rendahnya self-esteem dan self-beliefs sebagai pebelajar dan membandingkan performa antarsiswa daripada perbaikan personal (Alkharusi, 2011, 2015; Black $\&$ Wiliam, 2006; Budiyono, 2010). Praktik tradisional yang menjadi budaya di kelas tersebut sangat erat kaitannya dengan faktor-faktor baik dari eksternal (regulasi pemerintah, mandat atasan, perilaku siswa, lingkungan, dan kurikulum) dan internal (keahlian, keyakinan, pengetahuan dan pengalaman).

Serangkaian penilaian harus dapat memberikan informasi kepada siswa dan guru untuk masing-masing merefleksikan belajar dan pengajaran serta membuat perbaikan menuju tujuan yang ingin dicapai (Black \& Wiliam, 2010; Hattie \& Timperley, 2007). Hal ini sebagaimana temuan dari beberapa peneliti yang mengungkapkan bahwa penilaian yang terintegrasi dalam proses belajar mengajar dapat membantu siswa untuk meningkatkan belajarnya (Balan, 2010; Wiliam, Lee, Harrison, \& Black, 2004) dan membantu guru untuk meningkatkan kegiatan instruksionalnya (Shepard, 2000a, 2000b; Young \& Kim, 2010).

Upaya membangun keyakinan, pengetahuan dan literasi guru tentang penilaian akan lebih tertanam ketika masih berada pada periode pendidikan di perguruan tinggi (Siegel \& Wissehr, 2011; Volante \& Fazio, 2007). Calon guru perlu mendapat kesempatan untuk mengaplikasikan teori yang diperoleh untuk mengembangkan keahlian dan pengetahuan mereka. Di Indonesia, sebagian besar kurikulum di perguruan tinggi hanya menyediakan pengalaman praktis bagi calon guru ketika mereka melakukan Program Praktik
Lapangan (PPL) di tahun akhir masa perkuliahan. Minimnya pengalaman praktis bagi calon guru, mendorong penelitian ini untuk memaksimalkan peluang dari keadaan tersebut dengan melibatkan calon guru dalam kegiatan lesson study. Alasan masuk akal mengapa melibatkan calon guru dalam lesson study, di antaranya (1) memberikan pengalaman berharga tentang pengajaran, pembelajaran, penilaian, dan bagaimana berkolaborasi dalam komunitas; dan (2) mengembangkan kritik dan refleksi diri untuk meningkatkan kegiatan instruksional (Burroughs \& Luebeck, 2010; Myers, 2012).

Berdasarkan uraian di atas, peneliti ingin mendiskripsikan tentang bagaimana implementasi penilaian yang terintegrasi dalam proses belajar mengajar oleh calon guru dan apa saja perubahan yang dihasilkan dalam upaya meningkatkan praktik instruksional di kelas matematika. Penilaian yang terintegrasi dalam proses belajar mengajar ini kemudian disebut pembelajaran berbasis penilaian (assessment-based learning) dan disingkat dengan $A B L$. Pada dasarnya, $A B L$ mirip dengan penilaian otentik, namun lebih bersifat informal. Setidaknya terdapat empat komponen utama yang harus diperhatikan dalam implementasi $A B L$ sehingga dapat berjalan efektif, yakni tujuan dan kriteria sukses, pertanyaan efektif, umpan balik formatif, serta penilaian diri dan sejawat (Black, Harrison, Lee, Marshall, \& Wiliam, 2004; Lee, 2006). Keberhasilan dari implementasi $A B L$ didasarkan pada asas keterlaksanaan dan kebermanfaatan. Keterlaksanaan dalam hal ini mengandung makna bahwa implementasi $A B L$ secara garis besar dapat dilakukan oleh semua partisipan secara nyaman. Adapun kebermanfaatan lebih difokuskan pada aspek perbaikan dan peningkatan instruksional.

\section{METODE}

Penelitian mengadopsi participatory action research (PAR) yang mencakup prosedur lesson study di dalamnya. PAR merupakan pendekatan eksplorasi siklik dalam menginvestigasi isu, mengonstruksi pengetahuan, dan merefleksikan praktik dengan melibatkan aktivitas kolaborasi partisipatif dalam proses riset maupun upaya melakukan perubahan yang lebih baik (Kemmis, McTaggart, \& Nixon, 2014; McTaggart, 1997). Keunikan dalam PAR adalah kolaborasi antara praktisi (partisipan) dan akademisi (peneliti) yang memiliki ikatan berupa komitmen untuk 
mengonseptualisasikan, mempraktikkan, dan mempertimbangkan penelitian guna menanggapi atau memperbaiki praktik sosial.

Subjek penelitian ini adalah lima calon guru sekolah dasar yang melakukan praktik pengalaman lapangan di salah satu sekolah dasar di Jakarta Timur. Lima partisipan (yang selanjutnya disebut guru-partisipan) tersebut adalah mahasiswa semester tujuh. Peneliti membimbing mereka dalam praktik pengalaman lapangan selama 4 bulan.

Prosedur penelitian ini dimulai dengan memberikan gambaran tentang penelitian dan diskusi terkait apa, mengapa, dan bagaimana menerapkan $A B L$. Kemudian, dilanjutkan dengan pertemuan-pertemuan terkait perencanaan lesson (antisipasi didaktis, menetapkan tujuan dan kriteria sukses pembelajaran, membuat media dan alat peraga, mendesain lesson, dan menyusun alat evaluasi di setiap sesi), aksi dan observasi, diskusi dan analisa terhadap aksi pengajaran. Prosedur tersebut tercakup dalam prosedur lesson study yakni rencana lesson, aksi dan observasi, serta evaluasi dan revisi (Fernandez \& Yoshida, 2004; Murata, 2011; Triwaranyu, 2007). Prosedur lesson study dalam PAR dapat dilihat pada Tabel 1.

Secara keseluruhan, terjadi 16 sesi pertemuan dan 10 praktik pengajaran. Semua pengajaran dilakukan di kelas IV dengan empat aksi pertama terkait bahasan faktor persekutuan terbesar dan kelipatan persekutuan terkecil, tiga aksi berikutnya terkait bahasan tentang mengukur dan menentukan besar sudut, dan tiga aksi terakhir terkait bahasan tentang hubungan antar satuan waktu. Praktik pengajaran dilakukan secara berurutan dan bergilir di antara lima guru-partisipan, sehingga masing-masing mendapat kesempatan dua kali pengajaran.

Data dikumpulkan dari berbagai sumber untuk memungkinkan triangulasi. Setiap sesi kegiatan atau aksi guru-partisipan di kelas direkam untuk kemudian dianalisis dan dikodekan. Dua observer menulis catatan lapangan untuk setiap sesi pengajaran. Di setiap sesi pengajaran, gurupartisipan dan siswa menulis jurnal reflektif dari pembelajaran yang dilakukan. Wawancara dilakukan selama sesi diskusi dan di akhir penelitian yang dikodekan berdasarkan fenomena atau pola yang menarik. Transkip wawancara divalidasi oleh guru-partisipan yang dikenai wawancara. Lembar tugas siswa juga digunakan sebagai sumber tambahan.

Analisis data dilakukan dengan teknik kualitatif lewat pengodean dan identifikasi indikator potensi perubahan praktik selama studi yang dianalisis dari dokumen tertulis, tanggapan tertulis dari dua observer, wawancara, dan rekaman video. Penggunaan kode untuk mengidentifikasi aksi

\section{Tabel 1. Prosedur Lesson study dalam PAR}

\begin{tabular}{|c|c|c|}
\hline Proses & Aktivitas & Hasil \\
\hline \begin{tabular}{lr}
\multicolumn{2}{l}{ Memberikan } \\
gambaran & tentang \\
penelitian & dan \\
gambaran & tentang \\
$A B L$ & \\
\end{tabular} & $\begin{array}{l}\text { - Mendiskusikan tentang gambaran } \\
\text { singkat penelitian dan peran } \\
\text { partisipan. } \\
\text { - Mendiskusikan apa, mengapa, dan } \\
\text { bagaimana implementasi } A B L \text {. }\end{array}$ & $\begin{array}{l}\text { - Tujuan dan gambaran penelitian } \\
\text { diutarakan secara jelas. } \\
\text { - Pengetahuan baru terkait } \\
\text { pembelajaran berbasis penilaian. }\end{array}$ \\
\hline $\begin{array}{l}\text { Merencanakan } \\
\text { lesson }\end{array}$ & $\begin{array}{l}\text { - Mendiskusikan tentang lesson atau } \\
\text { membuat rencana lesson yang } \\
\text { terintegrasi } A B L \text {. } \\
>\text { Interaksi antar guru-partisipan } \\
>\text { Interaksi antara guru-partisipan } \\
\text { dan peneliti }\end{array}$ & Rencana awal lesson. \\
\hline $\begin{array}{l}\text { Aksi dan } \\
\text { observasi* }\end{array}$ & $\begin{array}{l}\text { Salah satu guru-partisipan mengajar } \\
\text { (dua guru-partisipan melakukan } \\
\text { observasi dan satu guru-partisipan } \\
\text { yang lain merekam pembelajaran). }\end{array}$ & $\begin{array}{l}\text { Rekaman data dari situasi didaktis- } \\
\text { pedagogis. }\end{array}$ \\
\hline Evaluasi* & $\begin{array}{l}\text { - Diskusi untuk refleksi dan evaluasi. } \\
\text { Interaksi antar guru-partisipan } \\
>\text { Interaksi antara guru-partisipan } \\
\text { dan peneliti }\end{array}$ & Saran/ ide baru/ pengetahuan baru. \\
\hline Revisi* & Merevisi lesson & Lesson terevisi \\
\hline
\end{tabular}


pengajaran yang berkaitan dengan implementasi $A B L$.

\section{HASIL DAN PEMBAHASAN}

Analisis yang dipaparkan adalah pola umum yang dihasilkan dan teridentifikasi dari tiga atau lebih sumber data dan kecenderungan dari kelima guru-partisipan ketika menerapkan empat komponen $A B L$. Keempat komponen tersebut selanjutnya dianalisis implementasinya ke dalam beberapa poin berikut.

\section{Penetapan Tujuan dan Kriteria Sukses}

Analisis keterlaksanaan komponen ini diperoleh dari catatan pada jurnal guru maupun siswa, wawancara, dan rekaman video. Berdasarkan analisis ketiga sumber data tersebut, semua aksi guru-partisipan di kelas telah mengimplementasikan strategi ini. Guru-partisipan mengkomunikasikan tujuan dan kriteria sukses dengan cara menuliskannya di papan tulis sebelum mereka menyampaikan materi dan tidak menghapusnya selama kegiatan pengajaran. Mereka menghapusnya ketika siswa mengerjakan lembar evaluasi di akhir pengajaran. Kemudian, di akhir sesi pengajaran, siswa diminta kembali menuliskan tujuan dan kriteria sukses dalam jurnal belajar mereka sesuai dengan bahasa dan apa yang telah mereka dapatkan selama pembelajaran pada saat itu. Aktivitas mengisi jurnal juga dilakukan oleh guru-partisipan di setiap akhir pelajaran.

Berdasarkan wawancara dan diskusi yang dilakukan pada pertemuan ketiga, guru-partisipan menyadari pentingnya mengkomunikasikan tujuan belajar dan kriteria sukses sebelum instruksional dimulai karena membantu siswa dalam menentukan arah pembelajaran dan untuk merefleksi sejauh mana kriteria sukses tersebut tercapai. Hal ini secara langsung berkaitan dengan penilaian diri terhadap apa yang akan dilakukan, apa yang telah dilakukan, dan untuk apa dilakukan. Hal ini sebagaimana yang diungkapkan oleh Sisis dalam petikan wawancara berikut:

$R$ : ... Perubahan apa yang kamu rasakan selama pembelajaran ketika mengartikulasikan tujuan dan kriteria sukses tersebut?

S: ... Setelah dibiasakan dengan strategi ini, siswa lebih memaknai poin-poin yang telah mereka pelajari sebelumnya, sehingga ketika saya memulai dengan menghubungkan konten yang akan dipelajari dan konten sebelumnya, mereka lebih siap diri.
Hal ini juga sebagaimana yang diungkapkan oleh Siput:

Siswa lebih mengetahui poin-poin apa saja yang akan dipelajari. Siswa juga dapat membuat daftar dari poin-poin yang mereka belum pahami secara lebih spesifik yang ditulis dalam jurnal mereka di akhir pelajaran, sehingga saya dapat memberikan penekanan di poin-poin tersebut.

Pernyataan di atas sejalan dengan yang diungkapkan oleh Lee (2006), bahwa menetapkan tujuan belajar mengandung makna bahwa siswa akan memahami apa yang mereka pelajari dan dapat menilai kemajuannya dalam belajar. Sedangkan, kriteria sukses memberitahu siswa tentang apa saja yang harus mendapatkan perhatian lebih pada kegiatan mereka dalam rangka untuk mendapatkan tujuan pembelajaran yang diinginkan.

\section{Penekanan lebih terkait Pertanyaan Terbuka}

Pertanyaan adalah sembarang bentuk kalimat interogatif baik verbal dan nonverbal untuk mengomunikasikan materi kepada seseorang untuk tujuan-tujuan tertentu. Tujuan tersebut di antaranya digunakan untuk (1) meninjau, memeriksa, menyelidiki dan merangsang ide, proses berpikir dan pemahaman mereka, (2) mengajukan masalah, (3) mencari solusi alternatif, (4) mengembangkan sikap dan motivasi untuk terlibat dalam proses pembelajaran, (5) membangun pengetahuan dan mendorongnya untuk mengartikulasikan apa yang diketahui (Bonne \& Pritchard, 2007; Lee, 2006; Redhana, 2012, 2014).

Beberapa peneliti menyarankan beberapa strategi yang dapat diterapkan untuk mendukung efektivitas pertanyaan, di antaranya (1) memaksimalkan pertanyaan terbuka, salah satunya dengan mengeksplorasi pertanyaan dengan teknik probing dan menciptakan respon lanjutan berupa pertanyaan lebih lanjut segera (Black, Harrison, Lee, Marshall, \& Wiliam, 2003; Black et al., 2004; Lee, 2006; Redhana, 2014), (2) mengeksplorasi respon terutama contoh jawaban yang salah dan miskonsepsi umum untuk sumber diskusi kelas (Lee, 2006), (3) menyediakan waktu untuk berpikir (waiting time) (Black et al., 2003, 2004), dan (4) menggunakan strategi "no hands up" kecuali untuk memberikan kesempatan siswa untuk mengajukan pertanyaan atau beragumen (Black et al., 2003, 2004; Lee, 2006).

Selama aksi mereka, guru-partisipan menggunakan aturan "tanpa unjuk jari” dengan menem- 
pel poster "tangan yang disilang" dengan maksud untuk menghindari persaingan antar siswa ketika diberikan pertanyaan. Aturan ini tidak berlaku untuk siswa yang ingin mengajukan pertanyaan atau mengomentari argumen teman dan gurunya. Namun demikian, pada tiga aksi pertama, mengacungkan tangan masih menjadi kebiasaan siswa dalam menjawab pertanyaan. Hal ini sebagaimana yang dinyatakan oleh Nonik ketika sesi diskusi pada pertemuan keempat: "ketika siswa diberi pertanyaan, mereka berebut ingin menjawab, namun ketika salah satu di antara mereka diberikan kesempatan seringkali mereka diam dan tidak menjawab karena hanya ikut-ikutan". Hal ini juga dinyatakan oleh Nita bahwa "siswa hanya menggaungkan jawaban teman yang didengarnya sebelum dia berpikir tentang pertanyaan yang diberikan kepadanya".

Berdasarkan tiga aksi pertama tersebut, permasalahan yang dapat diidentifikasi yakni guru-partisipan masih menggunakan pertanyaan yang bersifat "pertanyaan kelas" yakni berada di depan kelas dan mengajukan pertanyaan kepada seluruh kelas. Hal ini mengarahkan siswa untuk bersaing dalam menjawab dan atau diam karena mereka percaya tidak lama kemudian guru akan menjawab sendiri pertanyaan tersebut. Berdasarkan hasil refleksi dan revisi, seluruh guru-partisipan mencoba untuk meminimalisir pertanyaan kelas dan mengarahkan pertanyaan kepada siswa secara acak dengan menggunakan nomor absen di aksi selanjutnya. Semua gurupartisipan menyadari bahwa dengan mengajukan pertanyaan secara acak kepada siswa memberikan dampak yang signifikan terhadap peningkatan fokus siswa terhadap pertanyaan dan siswa merasa dirinya memiliki kesempatan yang sama untuk mendapatkan pertanyaan.

Berdasarkan hasil pengkodean terhadap rekaman video, wawancara, catatan pada jurnal guru, dan lembar observasi dari lima guru-partisipan, mereka menyadari untuk memberikan penekanan lebih terhadap bagaimana menggunakan pertanyaan terbuka. Strategi ini sulit untuk mereka lakukan karena belum terbiasa menyiapkan pertanyaan apa saja yang dapat merangsang pendapat siswa. Namun demikian, mereka mengambil alternatif dengan mengeksplorasi pertanyaan dengan teknik probing. Hal ini dapat diverifikasi dari hasil rekaman video, lembar observasi, dan wawancara bahwa itensitas guru-partisipan menghampiri siswa ke belakang dan mengajukan probing ques- tions lebih meningkat ketika mereka menyadari strategi pertanyaan kelas tidak efektif.

Terdapat fakta menarik ketika siswa ingin bertanya atau berpendapat terhadap contoh atau kasus, yakni siswa maju sendiri ke depan untuk berkonsultasi terhadap tugas yang mereka anggap perlu klarifikasi dan validasi dari gurunya. Hal ini menurut peneliti adalah situasi positif yang mengarahkan siswa dan guru-partisipan berdialog satu-satu sehingga satu sama lain dapat mendapatkan umpan balik terhadap kinerja mereka masing-masing.

Seiring meningkatnya itensitas probing questions, keterampilan menyediakan waktu berpikir kepada siswa terlihat lebih jelas pada dua periode penting yaitu (1) waiting time 1, yakni interval antara berakhirnya pertanyaan guru dan dimulainya respon siswa dan (2) waiting time 2 , akumulasi jeda antara jawaban/argumen siswa sebelum guru atau siswa lain melakukan elaborasi atau penjelasan lebih lanjut. Hal ini sebagaimana yang dinyatakan beberapa peneliti bahwa menyediakan waktu untuk berpikir pada dua periode tersebut memiliki beberapa keuntungan, di antaranya (1) siswa memiliki waktu yang lebih untuk memikirkan jawaban berdasarkan buktibukti yang lebih logis dan mendalam; (2) kualitas dan kuantitas respon siswa (dan pertanyaan elaborasi guru sendiri) meningkat; (3) mereduksi kesalahan dalam merespon; (4) siswa lebih yakin dengan apa yang akan disampaikan. Di lain pihak, tanpa menunggu waktu berpikir, siswa akan sering memilih untuk tidak menanggapi atau hanya menggaungkan respon cepat atau pendapat dari rekan (Burton \& Habenicht, 2003).

Peneliti berpendapat bahwa kurangnya keahlian guru-partisipan dalam menyediakan pertanyaan terbuka di atas juga disebabkan oleh lemahnya pengetahuan mereka tentang konten epistemologis yang memiliki peran sebagai fundasi untuk mengkonstruksi konten matematis dalam pertanyaan terbuka yang diajukan. Peneliti menyebutnya dengan istilah pengetahuan konten epistemologis yakni pengetahuan yang digunakan untuk merefleksikan konten secara epistemologi. Pengetahuan yang kuat terhadap konten harus dapat merefleksikan struktur matematika secara epistemologis untuk memperkuat landasan dari konten yang diajarkan. Pengetahuan ini dapat dicontohkan ketika guru mengajukan pertanyaan terbuka terkait faktor persekutuan terbesar, guru harus memiliki pengetahuan yang kuat tentang 
konsep dari teorema fundamental aritmatika. Kasus lain dapat dicontohkan oleh seorang guru dalam mengajarkan konsep pembagian pecahan, guru harus dapat merefleksikan pengalaman dan pengetahuan mereka ketika bekerja dengan bilangan cacah, yaitu tentang konsep pembagian sebagai repeated subtraction, sebagai equal sharing, dan sebagai equal grouping, sebagai landasan untuk mengajarkannya.

\section{Umpan Balik Formatif, Penilaian Diri dan Sejawat}

Umpan balik merupakan unsur penting dalam penilaian (Hattie \& Timperley, 2007) karena pada dasarnya peran penilaian adalah menyediakan dan memberikan umpan balik kepada "pengguna". Dengan kata lain, menyampaikan tujuan dan kriteria sukses, menyediakan pertanyaan efektif, menyediakan kesempatan untuk melakukan penilaian diri dan sejawat adalah serangkaian kegiatan yang saling terintegrasi untuk menyediakan dan menghasilkan umpan balik.

Hattie dan Timperley (2007) berpendapat bahwa umpan balik dapat efektif apabila siswa dan atau guru mampu menciptakan situasi yang menjawab pertanyaan: Ke mana akan melangkah? Sejauh mana posisinya terhadap tujuan yang akan dicapai? Bagaimana akan melangkah selanjutnya? Umpan balik tersebut dapat diupayakan dengan memaksimalkan penilaian diri dan sejawat. Hal ini sebagaimana dinyatakan oleh beberapa peneliti bahwa penilaian-diri dan sejawat memungkinkan siswa dan atau guru untuk menerima dan memahami umpan balik yang berupa apa yang akan capai, di mana posisinya saat ini, dan bagaimana pendekatan untuk mencapai kriteria sukses yang telah ditetapkan (Black dkk, 2003, 2004; Lee, 2006). Black et al. (2004) dan Lee (2006) berpendapat bahwa penilaian diri dan sejawat adalah sarana menciptakan umpan balik dengan melibatkan siswa dalam berdialog tentang belajar mereka dan oleh karena itu membantu mereka untuk menjadi kritik diri dan mandiri.

Seiring dengan meningkatnya itensitas melakukan probing questions dan menyediakan waiting time 2 , umpan balik yang dilakukan gurupartisipan untuk mengklarifikasi jawaban dilakukan dengan lebih bermakna. Bermakna dalam hal ini mengandung arti bahwa guru-partisipan lebih menekankan pada proses bagaimana siswa memperoleh jawaban dan lebih dapat mengatur ritme umpan balik dengan melontarkan masalah kepada siswa lain ketika siswa mengalami hambatan ketika menjawab atau setelah siswa mendekati jawaban akhir dari pertanyaan.

Di samping itu, berdasarkan dokumen guru, dokumen siswa, catatan observer, dan rekaman video, guru-partisipan juga menggunakan umpan balik berupa komentar konstruktif terhadap tugas anonim siswa, yakni memberikan pernyataan atau pertanyaan yang mengarah dan membimbing jawaban siswa ke arah solusi, tanpa pemberian skor (skor disimpan oleh guru-partisipan sebagai arsip), dan diberikan kepada orang tua serta ditandatangani untuk mendapat umpan balik korektif. Strategi ini mendapatkan beberapa keuntungan, yaitu (1) siswa memahami kesalahan mereka tanpa harus secara eksplisit diberi tanda benar atau salah pada pekerjaan mereka; (2) terdapat peran aktif orang tua untuk mengetahui perkembangan belajar siswa, meskipun skor dari pekerjaan anaknya tidak dicantumkan; (3) siswa dan orang tua saling bersinergi untuk memperbaiki tugas.

Pada percobaan pertama, terdapat 4 dari 47 lembar pekerjaan siswa yang sulit diminta kembali oleh guru-partisipan karena lupa atau hilang. Hal ini kemudian disiati oleh guru-partisipan dengan memberikan surat kepada orang tua siswa untuk memberikan perbaikan, ditandatangani, dan dikembalikan dipertemuan selanjutnya.

Kekurangan terjadi ketika strategi-strategi dalam penilaian sejawat belum dapat diidentifikasi dengan jelas. Hal ini sangat masuk akal dikarenakan situasi dan kondisi kelas yang memiliki 47 siswa. Guru-partisipan mencoba melakukan strategi dengan cara membuat kelompok-kelompok kerja, namun karena jumlah siswa melebihi kuota dan kondisi ruangan yang sempit menyebabkan strategi ini belum maksimal. Guru-partisipan sulit berkeliling untuk memantau, membimbing, dan mengkondisikan siswa sedemikian sehingga siswa kurang maksimal dalam berdiskusi, saling beragumen, melakukan masing-masing tugas di dalam kelompoknya. Guru-partisipan juga telah menyediakan kegiatan untuk saling mengoreksi pekerjaan teman sejawat secara anonim. Namun demikian, kebiasaan siswa memberikan tanda benar atau salah serta memberikan skor menyebabkan strategi ini asing bagi siswa sehingga kesulitan dalam memberikan komentar deskriptif dan konstruktif untuk pekerjaan temannya.

Kekurangan di atas disiasati oleh gurupartisipan dengan menyediakan alternatif strategi yakni menyediakan aktivitas presentasi lisan 
oleh siswa. Siswa diberikan sebuah contoh atau kasus yang diminta untuk mengerjakan di depan, kemudian menjelaskannya kepada kelas, yang dengan arahan dan bimbingan guru-partisipan, siswa lain diberi kesempatan untuk mengomentari pekerjaan atau penjelasan siswa yang maju ke depan. Presentasi lisan merupakan salah satu metode penilaian yang menyediakan aktivitas penilaian diri dan sejawat (Ma, Millman, \& Wells, 2008), untuk mengkomunikasikan ide dan mengklarifikasi pemahaman secara lisan (Lianghuo \& Mei, 2007). Penilaian sejawat dalam kegiatan presentasi lisan terjadi ketika siswa memberikan argumen terhadap jawaban atau penjelasan siswa, sedangkan penilaian diri terjadi ketika komentar dari teman menjadi sebuah kritik diri atau refleksi diri untuk mengklarifikasi jawaban semula.

\section{PENUTUP}

Hasil penelitian menemukan bahwa calon guru (guru-partisipan) berupaya untuk memodifikasi praktik pembelajarannya dan meningkatkan perhatian terhadap unsur pertanyaan terbuka dan penilaian sejawat secara kolaboratif. Secara umum, guru-partisipan telah mengimplementasikan dan mengintegrasikan setiap komponen $A B L$ ini satu dengan yang lain. Perbaikan instruksional juga terjadi seiring dengan perbaikan dalam mengimplementasikan $A B L$. Hal ini terkait dengan umpan balik yang diterima oleh guru-partisipan dan memaksimalkannya menjadi sebuah cara untuk merancang perbaikan instruksional.

Guru-partisipan juga mendapatkan umpan balik secara langsung untuk merefleksi diri dan mendapat masukan dari teman sejawat melalui serangkaian kegiatan dalam lesson study. Dengan kata lain, lesson study dapat dianggap sebagai salah satu pendekatan yang jitu untuk menyediakan kesempatan bagi calon guru melakukan penilaian diri dan sejawat guna membimbing dan memperbaiki praktik instruksional mereka di kelas. Lesson study juga menjadi sarana penting untuk memediasi kesenjangan antara teori (termasuk hasil-hasil penelitian) dan praktik di kelas. Calon guru dapat mendapatkan pengalaman nyata bagaimana mengembangkan dan merevisi pengetahuan mereka tentang penilaian dalam upaya mendukung belajar dan mengajar matematika di sekolah dasar.

Pentingnya pengalaman praktis bagi calon guru perlu disikapi oleh pembuat kebijakan di level perguruan tinggi untuk mengintegrasikan pengalaman lapangan secara berkesinambungan dan bukan hanya di akhir masa perkuliahan. Hal ini berguna untuk memberikan kesempatan calon guru untuk merefleksi diri terkait praktik pengajaran di kelas sebagai sebuah cara untuk mengembangkan pengetahuan dan keahlian mereka. Hal ini dapat dilakukan dengan beberapa cara, di antaranya adalah: (1) melibatkan calon guru dalam kegiatan lesson study baik baik dirinya sendiri atau guru contoh sebagai subjek; (2) membuat program untuk memberikan kesempatan calon guru untuk observasi ke sekolah-sekolah; dan (3) melibatkan calon guru dalam kegiatan penelitian secara berkesinambungan. Penelitian ini juga merekomendasikan pentingnya mengembangkan pengetahuan konten dan penilaian dan pengetahuan konten epistemologis calon guru untuk mendukung pembelajaran matematika di kelas. Kedua pengetahuan ini berguna untuk membangun pemahaman konten yang komprehensif sedemikian sehingga dapat diaplikasikan untuk mempertinggi kualitas dalam melakukan pertanyaan terbuka dan penyediaan umpan balik.

\section{UCAPAN TERIMA KASIH}

Ucapan terima kasih disampaikan kepada Kementerian Riset Teknologi dan Pendidikan Tinggi, yang telah mendanai penelitian ini melalui program penelitian hibah fundamental sesuai surat perjanjian pelaksanaan penugasan program penelitian nomor: 113/K3/KM/2015. Peneliti juga mengucapkan terimakasih kepada Dr. Acep Kusdiwelirawan, M.Si. yang telah memberikan arahan dan masukan kepada penelitian ini.

\section{DAFTAR PUSTAKA}

Alkharusi, H. 2011. "Development and Datametric Properties of a Scale Measuring Students' Perceptions of the Classroom Assessment Environment". International Journal of Instruction, 4(1), hlm. 105-120.

Alkharusi, H. 2015. "An Evaluation of the Measurement of Perceived Classroom Assessment Environment". International Journal of Instruction, 8(2), hlm. 45-54.

Balan, A. 2010. Assessment for Learning: A Case Study in Mathematics Education. Doctoral Thesis. Malmö University, Holmbergs, Malmö. Retrieved from www.mah.se/muep (Malmö Studies in Educational Sciences No. 68) 
Black, P., Harrison, C., Lee, C., Marshall, B., \& Wiliam, D. 2003. Assessment for Learning: Putting it into Practice. Maidenhead, U.K.: Open university Press.

Black, P., Harrison, C., Lee, C., Marshall, B., \& Wiliam, D. 2004. "Working Inside the Black Box: Assessment for Learning in The Classroom". Phi Delta Kappan, 86(1), hlm. 9-21.

Black, P., \& Wiliam, D. 2006. "Assessment for Learning in the Classroom". Dalam J. Gardner (Ed.), Assessment and Learning (hlm. 9-26). London, UK: SAGE Publication Ltd.

Black, P., \& Wiliam, D. 2010. "Inside the Black Box: Raising Standards through Classroom Assessment". Phi Delta Kappan, 92(1), hlm. 81-90. doi: $10.1177 / 003172171009200119$

Bonne, L., \& Pritchard, R. 2007. Teacher Researchers Questioning Their Practice. Paper presented at the Proceedings of the 30th Annual Conference of the Mathematics Education Research Group of Australasia.

Budiyono. 2010. Peran Asesmen dalam Peningkatan Kualitas Pembelajaran. Paper presented at the Seminar Nasional Pendidikan Matematika, Surakarta.

Burroughs, E. A., \& Luebeck, J. L. 2010. "Preservice Teachers in Mathematics Lesson Study". The Mathematics Enthusiast, 7(2), hlm. 391-400.

Burton, L., \& Habenicht, D. J. 2003. "Getting Students to Think: Using Questions Effectively in the Classroom". Journal of Adventist Education, 66(1), hlm. 20-25.

Delandshere, G. 2002. "Assessment as Inquiry". The Teachers College Record, 104(7), hlm. 1461-1484.

Earl, L. M. 2003. Assessment as Learning: Using Classroom Assessment to Maximize Student Learning. Thousand Oaks, CA: Corwin Press.
Fernandez, C., \& Yoshida, M. 2004. Lesson Study: A Japanese Approach to Improving Mathematics Teaching and Learning. Mahwah, NJ: Lawrence Erlbaum Associates.

Hattie, J., \& Timperley, H. 2007. "The Power of Feedback". Review of educational research, 77(1), hlm. 81-112.

James, M., Black, P., Carmichael, P., Conner, C., Dudley, P., Fox, A., Marshall, B. 2006. Learning How to Learn: Tools for Schools. London: Routledge.

Kemmis, S., McTaggart, R., \& Nixon, R. (2014). The action research planner: Doing Critical Participatory Action Research. Singapore: Springer Science \& Business Media.

Lee, C. 2006. Language for Learning Mathematics: Assessment for Learning in Practice. Berkshire, England: Open University Press.

Lianghuo, F., \& Mei, Y. S. 2007. "Integrating Oral Presentation into Mathematics Teaching and Learning: An Exploratory Study with Singapore Secondary Students". The Montana Mathematics Enthusiast, Monograph, 3, hlm. 81-98.

Ma, X., Millman, R., \& Wells, M. 2008. "Infusing Assessment into Mathematics Content Courses for Pre-service Elementary School Teachers". Educational Research for Policy and Practice, 7(3), hlm. 165-181. doi: 10.1007/s10671-008-9050-5

McTaggart, R. (1997). "Guiding Principles for Participatory Action Research". Dalam R. McTaggart (Ed.), Participatory action research: International contexts and consequences (hlm. 25-43). Albany: State University of New York Press.

Murata, A. (2011). "Introduction: Conceptual overview of lesson study". Dalam L. Hart, A. Alston \& A. Murata (Eds.), Lesson study research and practice in mathematics education (hlm. 1-12). Dordrecht: Springer Science+Business Media B.V. 
Myers, J. 2012. "Lesson Study as a Means for Facilitating Preservice Teacher Reflectivity". International Journal for the Scholarship of Teaching and Learning, 6(1), hlm. 15.

Redhana, I. W. 2012. "Model Pembelajaran Berbasis Masalah dan Pertanyaan Socratik untuk Meningkatkan Keterampilan Berpikir Kritis Siswa". Cakrawala Pendidikan, XXXI(3), hlm. 351-365.

Redhana, I. W. 2014. "Pengaruh Model Pembelajaran Seminar Socrates terhadap Hasil Belajar Siswa”. Cakrawala Pendidikan, XXXIII(1), hlm. 27-38.

Shepard, L. A. 2000a. "The role of assessment in a learning culture". Educational researcher, 29(7), hlm. 4-14. doi: 10.3102/0013189X029007004

Shepard, L. A. 2000b. The Role of Assessment in Teaching and Learning. Santa Cruz \& Los Angeles, CA: CRESST/CREDE, University of California.

Siegel, M. A., \& Wissehr, C. 2011. "Preparing for the Plunge: Preservice Teachers' As- sessment Literacy". Journal of Science Teacher Education, 22(4), hlm. 371-391. doi: 10.1007/s10972-011-9231-6

Triwaranyu, C. 2007. "Models and Strategies for Initial Implementation of Lesson Study in Schools". Paper presented at the International Forum of Teaching and Studies.

Volante, L., \& Fazio, X. 2007. "Exploring Teacher Candidates' Assessment Literacy: Implications for Teacher Education Reform and Professional Development". Canadian Journal of Education, 30(3), hlm. 749770 .

Wiliam, D., Lee, C., Harrison, C., \& Black, P. 2004. "Teachers Developing Assessment for Learning: Impact on Student Achievement". Assessment in Education, 11(1), hlm. 4965. doi: 10.1080/0969594042000208994.

Young, V. M., \& Kim, D. H. 2010. "Using assessments for Instructional Improvement: A Literature Review". Education Policy Analysis Archives, 18(19), hlm. 1-36. 